\title{
Different patterns of university students' integration of lecture podcasts, learning materials, and lecture attendance in a psychology course
}

\author{
Silke Luttenberger ${ }^{1}$ - Daniel Macher $^{2}$ - Verena Maidl ${ }^{2}$. \\ Christian Rominger ${ }^{3} \cdot$ Nilüfer Aydin $^{4} \cdot$ Manuela Paechter $^{2}$ (D)
}

Received: 26 November 2016 / Accepted: 16 February 2017 / Published online: 1 March 2017

C The Author(s) 2017. This article is published with open access at Springerlink.com

\begin{abstract}
Lecture podcasts are considered an efficient means for passing on learning contents to students, most notably in lectures with large numbers of students. Here, the lecturer's presentation, combined with lecture slides, is recorded and broadcasted in video form. The present study investigates how students organize learning when they have the choice of different representations of content: face-to-face lectures, lecture recordings as video podcasts, and additional text material. Latent class analysis identified three groups with different patterns of integration of these representations of content: (1) students who focused on podcasts; (2) students who made little use of the different representations of content; (3) students who occasionally made use of the different learning opportunities. Students in group 1 with a focus on podcasts achieved best. They devoted more time to learning and made diligent use of a variety of learning strategies such as note-taking, generating summaries, or rehearsing with the podcasts. The results suggest providing different representations of content to take into account differences in learners' preferences and abilities. They speak in favor of podcasts, especially in lectures with a large audience. However, the results also show a group of learners who make minimal use of the various representations of content. Instructional measures should be taken to engage and support these students.
\end{abstract}

Manuela Paechter

Manuela.Paechter@uni-graz.at

1 Institute for Educational Sciences and Educational Research, University College of Teacher Education Styria, Graz, Austria

2 Institute of Psychology, Educational Psychology Unit, University of Graz, Graz, Austria

3 Institute of Psychology, Biological Psychology Unit, University of Graz, Graz, Austria

4 Institute of Psychology, Social Psychology Unit, Alpen-Adria University, Klagenfurt, Austria 
Keywords Lecture podcasts $\cdot$ Media in education $\cdot$ Postsecondary education $\cdot$ Adult learning $\cdot$ Learning strategies

\section{Introduction}

Nowadays, many universities record lectures and distribute them via broadcasting media to users who would otherwise have no access to them as well as to students on-site (Giannakos and Vlamos 2013). For the recording of lectures and their distribution over the internet for playback on personal computers or portable media devices the terms podcast lectures (Evans 2008; Pilarski et al. 2008), lecture podcasts (Abdous et al. 2012; Walls et al. 2010; Williams et al. 2016), or video podcasts (Kay 2012) are often employed. Typically, the lecturer's presentation is recorded as film, combined with the lecture slides, and broadcasted in video format (McGarr 2009). Students may use personal computers, notebooks, tablets as well as mobile phones or other mobile devices for viewing. Often, additional learning material is accessible as well, for example online material or textbooks, allowing students to access learning contents in different representations.

The current study focuses on this kind of learning scenario in which lecture podcasts, face-to-face lectures, and additional material in text form are provided. It investigates how students integrate face-to-face lectures, lecture podcasts, and additional learning material into their learning and the exam preparation.

\subsection{Learning and achievement in face-to-face lectures and with lecture podcasts}

In terms of desirable instruction characteristics such as interactivity with the learning material, interaction with a lecturer and co-students, or opportunities for self-regulated learning, lectures are a poor learning environment, especially when they are in the form of lectures with large numbers of participants (Gibbs et al. 1996 - they investigated courses with 100 to 225 participants; see also Paechter and Maier 2010; Paechter et al. 2010). Despite these disadvantages, some researchers have a more positive view of lectures. Dolnicar (2005) emphasizes that a lecturer can relate learning contents to students' prior knowledge and real-life experiences even ad-hoc in the lecture and make learning more meaningful. Lectures are also helpful in structuring students' view of knowledge in a field (McGarr 2009).

Compared to face-to-face lectures, podcast lectures offer more opportunities for selfregulated learning. They permit flexibility to learn when, where, and at the pace students want (O'Callaghan et al. 2015). Lecture captures may support learners in actively engaging with the learning content by allowing them to directly and repeatedly access a specific section of a presentation and to control the speed of the media file (Bolliger et al. 2010; Giannakos and Vlamos 2013). This is an important didactic feature in terms of cognitive load and mental effort (Mayer 2001; Salomon 1983). If a large amount of verbal and visual information is presented simultaneously and a given pace (as in a face-to-face lecture), learners' cognitive load and the necessary mental effort may become too high to achieve optimal understanding. Podcasts as well as face-to-face lectures demand a high degree of cognitive load for the ongoing integration of the lecturer's speech with the information on slides. However, in contrast 
to face-to-face lectures, podcast lectures allow learners to divide content into smaller and manageable sequences, which can be rehearsed as often as they wish, supporting note-taking and rehearsing processes as a result. Note-taking and completeness of notes are important learning strategy variables that influence achievement in lectures (Titsworth and Kiewra 2004).

In a survey by Lonn and Teasley (2009) students used video podcasts largely for reviewing concepts and issues raised in lectures that they had previously attended, thus taking advantage of both possibilities of delivery of content. The addition of lecture podcasts gives students a chance to listen to a lecture for the first time if they missed a class or to listen to a lecture that they attended in person additional times after the class session is over (Evans 2008; Hew 2009; McKinney et al. 2009; McCombs and Liu 2007). In others surveys, students reported that they could learn more by hearing the lectures again (Scutter et al. 2010) or that the podcasts helped them to better understand the topics of the lecture (Toppin 2011).

Despite these positive assessments, studies on achievement in podcast lectures showed ambiguous results (O'Callaghan et al. 2015). Giannakos and Vlamos (2013) compared the achievements of high school students who had learned only with video podcasts with the achievements in a face-to-face course. Students who had learned with podcasts performed better on tasks in which learning content had to be memorized but did less well in problem-solving tasks. This study, however, took place in a smaller course and, contrary to the podcast sequences, students in the face-to-face condition could interact with the lecturer. O'Bannon et al. (2011) found no differences in achievement when comparing students who had experienced lecture podcasts to students who had attended parallel lectures. In a study by Traphagan et al. (2010), students who had access to lecture podcasts as well as to face-to-face lectures did not differ in achievement from students who only had access to the face-to-face lectures.

One may criticize that studies on learning with podcasts often neglect that achievement is mediated by various factors, i.e. not only by characteristics of the media environment but also by a learner's abilities, her/his appraisal and evaluation of the learning contents, or the cognitive demands the learning contents and material pose upon a learner (Kozma 1991; Snow 1989). A further critic to studies on learning with lecture podcasts concerns the methodological approach. In many studies, participants are allocated to a specific media environment (face-to-face or podcast). In reality, learning contents are provided in different representations, for example as face-toface lectures, lecture podcasts, and/or additional learning material. When this is the case, students have choices regarding how they integrate different forms of content representation into their learning processes. Against this background, the present study attempts to consider differences between learners and to identify different patterns of integration of face-to-face lectures, lecture podcasts, and additional learning material.

\subsection{Satisfaction and emotions in face-to-face lectures and with lecture podcasts}

In most surveys on learners' experiences and satisfaction, learners argue in favor of lecture podcasts. The reasons for satisfaction with lecture podcasts and e-learning in general mainly lie in the opportunities for self-regulated learning (Kay 2012; McKinney and Page 2009; Paechter and Maier 2010; Paechter et al. 2010). In different surveys, students believed that lecture podcasts are related to more efficient learning and that they 
are more effective revision tools than textbooks, text material, or their own notes (Brittain et al. 2006; Evans 2008; Giannakos and Vlamos 2013). Some studies have investigated socio-emotional reactions of students. In a study by Homer et al. (2008) students felt motivated and invigorated by the lecturer shown in the podcasts. In other studies, students reported being less anxious when they could take notes from lectures they viewed later on their own without having to worry about missing important information (Owston et al. 2011), or that viewing lecture podcasts helped them to reduce their anxiety before a test situation (Pilarski et al. 2008; Traphagan et al. 2010).

However, not all students appreciate learning with lecture podcasts. In a study by Kazlauskas and Robinson (2012), almost a fifth of students preferred attending the face-to-face lecture over learning with podcasts. These students felt that they could concentrate better and absorb more in lectures. They also felt less isolated and more included than when learning with podcasts. These results speak for learner differences that have to be taken into account when evaluating different learning scenarios.

\subsection{Research questions}

There is a need for research that investigates realistic educational scenarios in which students can decide on their own how to use different sources of information (lectures, lecture podcasts, additional material) for their learning. Yet, for the instructional design of lectures and lecture captures it would be important to know how students use and combine different representations of content and how efficient they are. Against this background, the current study investigates learning in a realistic educational scenario and addresses three questions:

1. Can we identify subgroups of students, which differ in their patterns of how they integrate lecture podcasts, lectures, and additional material into their learning?

2. Do students with different patterns of integration of podcasts, lectures, and additional material differ with regard to academic achievement and course satisfaction?

3. Do students with different patterns of integration of podcasts, lectures, and material differ in the application of cognitive learning strategies (e.g., note-taking) or temporal resource strategies?

\section{Method}

\subsection{Participants, procedure}

A total of 611 students participated in the study (461 (75.5\%) women and $150(24.5 \%)$ men). The age of the participants varied between 18 and $51(M=23.11, S D=4.14)$. All students were enrolled in a lecture-based course on educational psychology; data were gathered from two consecutive years. Each course lasted one semester with one lecture per week (altogether 13 to 15 lectures).

In each lecture, the lecturer and her/his presentation were recorded onto video. Videos had been taken by a professional cameraman. The podcasts showed the slides plus a film of the lecturer's presentation. In all lectures, the students had access to additional learning material (text material that could be downloaded). Students finished 
the course by a written examination. They were asked which devices they mostly used for viewing the podcasts. Altogether, 645 answers were given (students could name several devices). Mostly, notebooks were used to view the podcasts $(65.9 \%)$, followed by PCs (15.4\%), tablet computers (5.4\%), smartphones $(3.1 \%)$, and other devices $(2.4 \%)$ (no answers $7.8 \%$ ).

In addition, employment of students was recorded: $45.4 \%$ had no employment next to their studies, $32.8 \%$ had a mini-job, $15.7 \%$ had a part-time employment and $3.6 \%$ a fulltime employment, $2.3 \%$ gave childcare as their occupation and $0.2 \%$ (one person) was on educational leave. A further $0.2 \%$ did not give any information regarding their occupation.

\subsection{Measures}

On the day of the examination, students filled in a questionnaire on how they had learned as participants in the lecture. Table 1 shows the different variables that were measured.

The items on cognitive learning strategies had been partly adapted from the Lernstrategien im Studium questionnaire (Learning strategies in academic studies; Wild 2000), a German adaptation of a selection of Motivated Strategies for Learning Questionnaire scales (Pintrich et al. 1991).

\section{Results}

\subsection{Identification of student groups with different patterns of integration of lecture podcasts, face-to-face lectures, and material}

A latent class analysis (LCA) was carried out to identify groups of students that differ with regard to their integration of podcasts, lectures, and materials. LCA uses maximum likelihood estimation to fit a hypothesized model in which membership in a specified number of latent classes is related to answers on the respective items, and to produce fitted probabilities of class membership for individuals. Each latent class can be interpreted as a sub-population with homogeneous profiles. LCA uses information citeria (AIC, BIC, adjusted BIC) to determine the ideal number of conceptually meaningful classes (Collins and Lanza 2010). LCA identified three groups of learners $(\mathrm{AIC}=4778.19, \mathrm{BIC}=4839.98$ and adjusted $\mathrm{BIC}=4795.54)$, a three-class solution fitted the data best. As further criterion, entropy and average class assignment probabilities were used. Entropy is a goodness-of-classification criterion, with higher values indicating a better fit. Average class assignment is an indicator for precision of the classification, values close to 1 indicate a high reliability of the classification (Geiser 2012). The results showed high classification accuracy (Entropy $=0.997$ ) and classification reliability (0.999-1.000). Individuals are classified with high certainty into their most likely latent class.

The three groups can be described as follows:

1. Focus on podcasts: The largest group of the sample, 416 students $(68.1 \%)$, reports to have watched nearly all of the podcasts. They attended only single face-to-face lectures and revised part of the learning material but used the material slightly more often than the other groups. 
Table 1 List of variables, item wordings, and rating scales

Variables, item wordings

Lecture attendance, use of material and podcasts

Lecture attendance

Use of additional learning material

Lecture podcasts

Temporal resource strategies

Time invested for preparing the examination

Cognitive learning strategies,

Taking notes from lectures: I took comprehensive notes from the lecture.

Taking notes from podcasts: I took comprehensive notes from the podcast lecture.

Generation of summaries from lectures:

I generated summaries of the main ideas from the lecture.

Generation of summaries from podcasts: I generated summaries of the main ideas from the podcast lecture.

Generation of summaries from additional material: I generated summaries of the main ideas of the learning material.

Frequency of viewing the podcasts: I watched a whole podcast or at least parts of it several times in order to get it into my head.

Satisfaction

Overall I am with the course ...

Academic achievement in the written examination

Grades

Percentage pass/fail
Rating scale

$6=$ nearly all lectures, $5=$ approximately $75 \%$, $4=$ approximately $50 \%, 3=$ approximately $25 \%, 2=$ single lectures, $1=$ none

$3=$ all, $2=$ part of the material, $1=$ none of the material used

$6=$ nearly all podcasts, $5=$ approximately $75 \%$, $4=$ approximately $50 \%, 3=$ approximately $25 \%, 2=$ single podcasts, $1=$ none

Number of hours

$1=$ very rarely to $6=$ very frequently

$1=$ very rarely to $6=$ very frequently

$1=$ very rarely to $6=$ very frequently

$1=$ very rarely to $6=$ very frequently

$1=$ very rarely to $6=$ very frequently

$1=$ very rarely to $6=$ very frequently

$1=$ very dissatisfied, $6=$ very satisfied

$1=$ excellent to $5=$ fail

Percentage between 0 and 100

2. Minimal use: A group of 120 students (19.6\%) made little use of the different representations of learning contents. They attended less than $25 \%$ of the lectures and very seldom watched the podcasts. This group partly used the additional material.

3. Occasional use of lectures, podcasts, and material: 75 (12.3\%) of the students made use of approximately $25 \%$ of the lectures and podcasts and partly used the learning material.

A univariate analysis of variance (ANOVA) was carried out to test for differences between the groups with regard to lecture attendance, podcast use, and use of learning 
material (see Table 2). ANOVA showed significant differences for lecture attendance, $F(2,606)=8.314, p<.001, \eta^{2}=.027$. Post-hoc tests showed the following significant differences between groups: $1=2,1<3,2=3\left(p_{1-2}=.453, p_{1-3}=.001, p_{2-3}=.079\right)$. A significant difference was found for the use of podcasts, $F(2,606)=2394.515$, $p<.001, \eta^{2}=.888$. Post-hoc tests showed the following significant differences between groups: $2<3<1(p<.001)$. An ANOVA found significant differences for the use of the learning material, $F(2,606)=5.100, p=.006, \eta^{2}=.017$. Post-hoc tests indicated significant differences between the three groups: $2<1,2=3\left(p_{1-2}=.034, p_{2-3}=.971\right)$, there was a statistical tendency for $3<1\left(p_{1-3}=.060\right)$.

\subsection{Differences with regard to academic achievement and satisfaction}

A non-parametric Kruskal-Wallis analysis of variance found significant differences in the grades of the three groups of learners, $\chi^{2}(2)=26.337, p<.001$ (see Table 3 ). Students in group 1 with a focus on podcasts exceeded students in both group 2 and 3 , while students in group 2 who nearly did not use podcasts at all and students in group 3 did not differ. U-tests found the following differences between groups: $(2=3)<1\left(p_{1-}\right.$ $\left.2<.001, p_{1-3}=.009, p_{2-3}=.295\right)$. Also, the proportion of students who failed the course was smallest in group 1: $9.9 \%$ compared to $26.7 \%$ in group 2 and $25.3 \%$ group $3\left(1<(2=3) ; \chi^{2}(2)=27.637, p<.001 ; p_{12}<.001, p_{13}<.001, p_{23}=.487\right)$.

With regard to course satisfaction, ANOVA became also significant, $F(2$, $604)=14.323, p<.001, \eta^{2}=.045$ (see Table 4). Students in group 1 with a focus on podcasts were more satisfied than learners in group 2 and group 3; there was also a statistical tendency that group 3 was less satisfied than group 1: $1>(2=3), 2=3\left(p_{1-}\right.$ $\left.2<.001, p_{1-3}=.086, p_{2-3}=.306\right)$.

\subsection{Differences with regard to time invested in learning and the use of learning strategies}

Students were asked how much time they had invested to prepare for the exam. An ANOVA found significant differences for this variable, $F(2,575)=16.694$, $p<.001, \eta^{2}=.055$ (see Table 5). Students in group 1 with a focus on podcasts invested more time than learners in group 2 and learners in group 3. Students

Table 2 Descriptive statistics for lecture attendance, podcast use, and use of additional material

\begin{tabular}{|c|c|c|c|c|c|c|c|c|}
\hline & \multicolumn{6}{|c|}{ Group } & & \\
\hline & 1 & & 2 & & 3 & \multicolumn{3}{|c|}{ Total } \\
\hline Variable & $M$ & $S D$ & $M$ & $S D$ & $M$ & $S D$ & $M$ & $S D$ \\
\hline Lecture attendance & 2.46 & 1.37 & 2.68 & 1.56 & 3.19 & 1.56 & 2.80 & 1.68 \\
\hline Podcast use & 5.85 & 0.52 & 1.66 & 0.81 & 3.55 & 0.66 & 4.50 & 1.96 \\
\hline Learning material & 2.45 & 0.57 & 2.30 & 0.56 & 2.28 & 0.56 & 2.40 & 0.57 \\
\hline
\end{tabular}

Note. Lecture attendance $(1=$ none; $6=$ nearly all $)$, podcast use $(1=$ none; $6=$ nearly all $)$, learning material $(1=$ none; 3 = all $)$ 
Table 3 Descriptive statistics for grades

\begin{tabular}{|c|c|c|c|c|c|c|c|c|}
\hline & \multicolumn{6}{|c|}{ Group } & & \\
\hline & 1 & & 2 & & 3 & \multicolumn{3}{|c|}{ Total } \\
\hline Variable & $M D$ & $M$ & $M D$ & $M$ & $M D$ & $M$ & $M D$ & $M$ \\
\hline Grades & 3 & 2.79 & 4 & 3.42 & 3 & 3.23 & 3 & 2.87 \\
\hline
\end{tabular}

Note. Grades $(1=$ excellent to $5=$ fail $)$

in group 3 did not differ from learners in group 2 with respect to time invested: $(2=3)<1\left(p_{1-2}<.001, p_{1-3}<.001, p_{2-3}=.530\right)$.

Furthermore, students were asked about their learning strategies. A multivariate analysis of variance MANOVA for the two variables on learning in lectures found no difference between the groups, $F(4,978)=2.202, p=.067, \eta^{2}=.009$ (see Table 6).

MANOVA indicated significant differences for the three variables on learning with podcasts, $F(6,1096)=15.585, p<.001, \eta^{2}=.079$. With regard to writing summaries from the podcasts, the following differences between the groups were found $(F(2$, $\left.549)=15.055, p<0.001, \eta^{2}=.052\right):(2=3)<1\left(p_{1-2}=.001, p_{1-3}<.001, p_{2-3}=.867\right)$. With regard to taking notes from podcasts the following differences were found $(F(2$, $\left.549)=32.203, p<.001, \eta^{2}=.105\right):(3=2)<1\left(p_{1-2}<.001, p_{1-3}<.001, p_{2-3}=.601\right)$. With regard to watching the podcasts the following differences were found $(F(2$, $\left.549)=23.315, p<0.001, \eta^{2}=.078\right):(3=2)<1\left(p_{1-2}<.001, p_{1-3}<.001, p_{2-3}=.204\right)$.

An ANOVA for writing summaries of the learning material showed no significant differences $\left(F(2,556)=2.465, p=.086, \eta^{2}=.009\right)$.

\section{Discussion}

\subsection{Different patterns of integration of lecture podcasts, face-to-face lectures, and material and their relation to achievement and satisfaction}

Latent class analysis identified three groups (research question 1):

- Group 1 with a strong focus on the use of podcasts who also used the learning material more frequently than others; the largest proportion of students $(68.1 \%)$ belongs to this group.

Table 4 Descriptive statistics for satisfaction

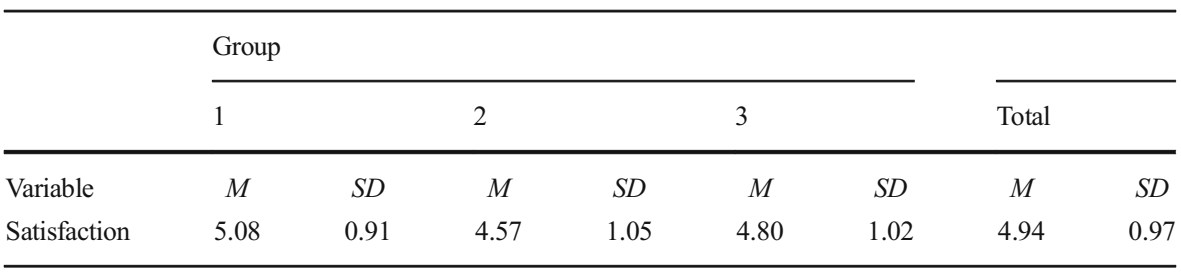

Note. Satisfaction $(1=$ very dissatisfied to $6=$ very satisfied $)$ 
Table 5 Descriptive statistics for time invested to prepare for the examination

\begin{tabular}{|c|c|c|c|c|c|c|c|c|}
\hline & \multicolumn{6}{|l|}{ Group } & \multirow{2}{*}{\multicolumn{2}{|c|}{ Total }} \\
\hline & 1 & & 2 & & 3 & & & \\
\hline Variable & $M$ & $S D$ & $M$ & $S D$ & $M$ & $S D$ & $M$ & $S D$ \\
\hline Time invested (hours) & 29.00 & 21.33 & 18.02 & 16.70 & 20.70 & 12.81 & 25.13 & 20.51 \\
\hline
\end{tabular}

- Group 2 material who made very little use of lectures or podcasts and used the additional material less frequently than group 1; 19.6\% belonged to this group.

- Group 3 who attended occasionally attended lectures and watched podcasts; $12.3 \%$ of the students belong to this group.

With regard to achievement and satisfaction (research question 2), students in group 1 with a focus on podcasts material came off best. Group 1 differed from the other ones in terms of learning behaviors (research question 3). Students in this group were diligent learners. They frequently applied temporal resource strategies as well as cognitive learning strategies (Pintrich et al. 1991). With $29 \mathrm{~h}$ they spent much more time on exam preparation than learners in groups 2 and 3. Setting aside enough time for learning is important for cognitive as well as for emotional factors in learning; it leaves room to apply cognitive and meta-cognitive strategies, maintains motivation, and prevents unpleasant experiences such as feelings of anxiety, tension, or time pressure (Macher et al. 2012; Pintrich and de Groot 1990; Zimmerman 1990). However, even though setting aside enough time for learning is important for achievement, the actual use of time is more crucial (Castaño-Muñoz et al. 2014). Students in group 1 integrated different representations of content in their learning processes, podcasts, the additional mainly text-based learning material, and at least some lectures. They especially differed from the other groups in their learning with the podcasts. Here, they applied cognitive

Table 6 Descriptive statistics for use of learning strategies

\begin{tabular}{|c|c|c|c|c|c|c|c|c|}
\hline & \multicolumn{6}{|c|}{ Group } & \multirow{2}{*}{\multicolumn{2}{|c|}{ Total }} \\
\hline & 1 & & 2 & & 3 & & & \\
\hline Variable & $M$ & $S D$ & $M$ & $S D$ & $M$ & $S D$ & $M$ & $S D$ \\
\hline I generated summaries of the main ideas from the lecture. & 3.37 & 1.96 & 3.59 & 1.92 & 3.29 & 1.89 & 3.48 & 1.95 \\
\hline I took comprehensive notes from the lecture. & 3.43 & 1.76 & 3.04 & 1.69 & 3.62 & 1.73 & 3.30 & 1.73 \\
\hline $\begin{array}{l}\text { I generated summaries of the main ideas from } \\
\text { the podcasted lecture. }\end{array}$ & 3.99 & 1.90 & 3.07 & 1.79 & 2.91 & 1.79 & 3.74 & 1.91 \\
\hline I took comprehensive notes from the podcasted lecture. & 4.82 & 1.58 & 3.37 & 1.90 & 3.72 & 1.79 & 4.40 & 1.72 \\
\hline $\begin{array}{l}\text { I watched a whole podcast or at least parts of it several } \\
\text { times in order to get it into my head. }\end{array}$ & 3.78 & 1.80 & 2.43 & 1.39 & 2.88 & 1.60 & 3.40 & 1.76 \\
\hline $\begin{array}{l}\text { I generated summaries of the main ideas } \\
\text { of the learning material. }\end{array}$ & 3.64 & 1.85 & 4.08 & 1.91 & 3.78 & 1.92 & 3.78 & 1.90 \\
\hline
\end{tabular}

Note. Scale range from $1=$ very rarely to $6=$ very frequently 
learning strategies which are of special importance for achievement in lectures such as note-taking, making summaries, and repeating contents (Caspi et al. 2005). The integration of complementary representations of content and the intense application of cognitive learning strategies for the podcasts enabled a richer understanding and a deeper knowledge (Zimmerman 1990). Not surprisingly, students in group 1 had the highest values in achievement and satisfaction.

The low achievements in group 2 can be explained by low effort in terms of time and access to the learning contents. These students made very little use of all representations of content. In her study on face-to-face lectures, Dolnicar (2005, p. 8) found a similar group of learners which she labeled as "minimalists" who seldom attended lectures and, when they did, mostly for pragmatic reasons such as not missing information that might be relevant for the examination. As expected, low effort was related to low achievement. It is understandable, that these students were also less satisfied with their course. The present data does not allow us to conclude precisely why students in group 2 did not exert more effort in learning. There are various possible explanations for these students' learning behaviors, for example personal characteristics and attitudes such as lower achievement goals and lower interest in the course and its topics (Pekrun 2006; Steinmayr and Spinath 2009), but also external variables such as university and study regulations. Further reasons for learning behavior and motivation in group 2 might lie in the instructional design and the combination of different forms of representation of content.

The main difference between group 2 and group 3 lies in the use of podcasts: Whereas students in group 2 neglected the podcasts students in group 3 at least watched about $25 \%$ of the podcasts. Students in group 3 also attended the lecture somewhat more frequently than students in group 1, which means that they attended a bit more than $25 \%$ of the lectures. Therefore, it is understandable that students in group 3 did not exceed group 2 and that they had significantly worse grades than students in group 1 .

Against this background, the question arises how one can explain achievements in the examination. Research points to a variety of variables that may explain achievement: cognitive, motivational, and emotional variables (e.g., prior knowledge, goals, anxiety) as well as learning behaviors and strategies. In the present study, of these variables only learning strategies could be recorded. The results show that in the most successful group increased use of podcasts was accompanied by the application of desirable cognitive and temporal learning strategies (Pintrich et al. 1991). Students took advantage of the specific characteristics of the podcasts such as the possibility to divide content into smaller sequences (Titsworth and Kiewra 2004) and applied strategies that are well suited to these characteristics.

\subsection{Focus on podcasts, neglect of face-to-face lectures}

Latent class analysis had identified one group who heavily relied on the lecture podcasts for learning and who comprised the majority of the sample. It appears that advantages of podcasts such as flexibility with regard to time and place and the support of learning strategies were well accepted by these students. In contrast, lecture attendance was very low in all three groups identified by latent class analysis. It, however, has to be remembered that the study investigated lectures with a large audience (on an average with more than 300 students who attended the examination). Important advantages of face-to-face courses over broadcasted content such as interactivity with 
a lecturer and co-students or the opportunity to build up a motivating social relationship with a lecturer (Paechter et al. 2013; Schweizer et al. 2001; Traphagan et al. 2010) do not come into effect in lectures with such a large audience.

The fear that lecture attendance may drop is an important reason instructors hesitate to introduce podcasts into their classrooms (Traphagan et al. 2010). Yet, empirical evidence for this fear is ambiguous (O'Callaghan et al. 2015). While some studies found no decreases in lecture attendance (Larkin 2010; Moss et al. 2010; Walls et al. 2010), others found that students skipped lectures, especially if podcasts were provided as a supplementary review resource (Brotherton and Abowd 2004; Traphagan et al. 2010). The low attendance rates in the present survey suggest a decrease in lecture attendance when podcasts are introduced. Attendance rate, however, may be influenced by different factors, such as characteristics and/or attitudes of the individual students (Gibbs et al. 1996) as well as course characteristics (e.g., the availability of additional material; Hove and Corcoran 2008; Traphagan et al. 2010), or cultures of learning in a university or even in an educational system (Schulmeister 2015).

\section{Limitations of the study}

When interpreting the results, one has to consider that the study was carried out in two courses on educational psychology. Participants were mainly psychology bachelor students and pre-service teachers who prepare for teaching psychology in secondary schools. The learning contents comprise fundamental topics of educational psychology on which most curricula and textbooks agree (e.g., cognitive and behaviorist learning theories; knowledge structures, learning motivation, research designs in educational psychology etc.). However, special importance was placed on students' understanding of research methods and methodology in psychology. Learning objectives of the course and of the examination tasks mainly referred to understanding and applying learning contents and only to a small degree to remembering and reproduction (for a taxonomy of learning objectives, see Anderson et al. (2001). Examination tasks were mostly single-choice tasks with one correct answer out of four and (few) tasks with open questions, which could be answered by keywords or short explanations. Generalizations of the results should consider the restriction of the study to a particular subject and a particular examination format.

\section{Conclusions}

A large majority of students in this study strongly relied on lecture podcasts for the exam preparation. These students were very successful in the exam. Despite many reservations of instructors (Brotherton and Abowd 2004; Traphagan et al. 2010), from the viewpoint of learners' achievements the results of the present study speak in favor of delivering learning contents as lecture captures and other representations to take into account differences between learners. While most students learned efficiently and were quite successful, two groups (a total of $31.9 \%$ ), achieved less. They made either overall minimal use of the podcasts, lectures, and additional material or they used all representations of content but only occasionally. In many instances, these students' effort 
was not sufficient to pass the exam. Instructional measures should be taken to engage and support these students, and as a first step, these students' motives for (not) learning should be explored further. Lecturers should be conscious of these students and do what they can to engage and to support them. To be sure, there are limitations to what can actually be provided in terms of support in lectures with large audiences. Measures such as clearly describing the importance of material for the examination, giving examples of exam questions, or trying to motivate students by various means are still possible even in this learning scenario.

Acknowledgements Open access funding provided by University of Graz.

Funding This study was funded by the Styrian Department for Science and Research.

\section{Compliance with ethical standards}

Conflict of interest The authors declare that they have no conflict of interest.

\section{References}

Abdous, M., Facer, B. R., \& Yen, C.-J. (2012). Academic effectiveness of podcasting: A comparative study of integrated versus supplemental use of podcasting in second language classes. Computers and Education, 58, 43-52. doi:10.1016/j.compedu.2011.08.021.

Anderson, L., Krathwohl, D. R., Airasian, P. W., Cruikshank, K. A., Mayer, R. E., Pintrich, P. R., Raths, J., \& Wittrock, M. C. (2001). A taxonomy for learning, teaching, and assessing. A revision of Bloom's taxonomy of educational objectives. New York: Longman.

Bolliger, D. U., Supanakorn, S., \& Boggs, C. (2010). Impact of podcasting on student motivation in the online learning environment. Computers \& Education, 55(2), 714-722. doi:10.1016/j.compedu.2010.03.004.

Brittain, S., Glowacki, P., van Ittersum, J., \& Johnson, L. (2006). Podcasting Lectures: Formative evaluation strategies helped identify a solution to a learning dilemma. Educause Quarterly, 3. Retrieved May 21, 2015.

Brotherton, J. A., \& Abowd, G. D. (2004). Lessons learned from eClass. ACM Transactions on ComputerHuman Interaction, 11(2), 121-155. doi:10.1145/1005361.1005362.

Caspi, A., Gorsky, P., \& Privman, M. (2005). Viewing comprehension: Students' learning preferences and strategies when studying from video. Instructional Science, 33(1), 31-47. doi:10.1007/s11251-004-2576-x.

Castaño-Muñoz, J., Duart, J. M., \& Sancho-Vinuesa, T. (2014). The internet in face-to-face higher education: Can interactive learning improve academic achievement? British Journal of Educational Technology, 45(1), 149-159. doi:10.1111/bjet.12007.

Collins, L. M., \& Lanza, S. T. (2010). Latent class and latent transition analysis. With applications in the social, behavioral, and health sciences. New Jersey: John Wiley \& Sons.

Dolnicar, S. (2005). Should we still lecture or just post examination questions on the web? The nature of the shift toward pragmatism in undergraduate lecture attendance. Quality in Higher Education, 11(2), 103115. doi:10.1080/13538320500175027.

Evans, C. (2008). The effectiveness of m-learning in the form of podcast revision lectures in higher education. Computers \& Education, 50(2), 491-498. doi:10.1016/j.compedu.2007.09.016.

Geiser, C. (2012). Data analysis with Mplus. New York: The Guilford Press.

Giannakos, M. N., \& Vlamos, P. (2013). Using webcasts in education: Evaluation of its effectiveness. British Journal of Educational Technology, 44(3), 432-441. doi:10.1111/bjet.12070.

Gibbs, G., Lucas, L., \& Simonite, V. (1996). Class size and student performance: 1984-94. Studies in Higher Education, 21(3), 261-273. doi:10.1080/03075079612331381201.

Hew, K. F. (2009). Use of audio podcast in K-12 and higher education: A review of research topics and methodologies. Educational Technology Research and Development, 57(3), 333-357. doi:10.1007 /s11423-008-9108-3. 
Homer, B. D., Plass, J. L., \& Blake, L. (2008). The effects of video on cognitive load and social presence in multimedia-learning. Computers in Human Behavior, 24(3), 786-797. doi:10.1016/j.chb.2007.02.009.

Hove, M. C., \& Corcoran, K. J. (2008). If you post it, will they come? Lecture availability in introductory psychology. Teaching of Psychology, 35(2), 91-95. doi:10.1080/00986280802004560.

Kay, R. H. (2012). Exploring the use of video podcasts in education: A comprehensive review of the literature. Computers in Human Behavior, 28(3), 820-831. doi:10.3991/ijet.v9i1.3335.

Kazlauskas, A., \& Robinson, K. (2012). Podcasts are not for everyone. British Journal of Educational Technology, 43(2), 321-330. doi:10.1111/j.1467-8535.2010.01164.x.

Kozma, R. B. (1991). Learning with media. Review of Educational Research, 61(2), 179-211. doi:10.3102 $/ 00346543061002179$.

Larkin, H. (2010). "But they won't come to lectures..." the impact of audio recorded lectures on student experience and attendance. Australasian Journal of Educational Technology, 26(2), 238-249. doi:10.14742/ajet.v26i2.1093.

Lonn, S., \& Teasley, S. D. (2009). Podcasting in higher education: What are the implications for teaching and learning? The Internet and Higher Education, 12(2), 88-92. doi:10.1016/j.iheduc.2009.06.002.

Macher, D., Papousek, I., Ruggeri, K., \& Paechter, M. (2012). Statistics anxiety and academic performance. European Journal of Psychology of Education, 27(4), 483-498. doi:10.1007/s10212-011-0090-5.

Mayer, R. B. (2001). Multimedia learning. New York, NY: Cambridge University Press.

McCombs, S., \& Liu, Y. (2007). The efficacy of podcasting technology in instructional delivery. International Journal of Technology in Teaching and Learning, 3(2), 123-134.

McGarr, O. (2009). A review of podcasting in higher education: Its influence on the traditional lecture. Australasian Journal of Educational Technology, 25(3), 309-321. doi:10.14742/ajet.v25i3.1136.

McKinney, A. A., \& Page, K. (2009). Podcasts and videostreaming: Useful tools to facilitate learning of pathophysiology in undergraduate nurse education? Nurse Education in Practice, 9(6), 372-376. doi:10.1016/j.nepr.2008.11.003.

McKinney, D., Dyck, J. L., \& Luber, E. S. (2009). iTunes university and the classroom: Can podcasts replace professors? Computers \& Education, 52(3), 617-623. doi:10.1016/j.compedu.2008.11.004.

Moss, N. D., O'Connor, E. L., \& White, K. M. (2010). Psychosocial predictors of the use of enhanced podcasting in student learning. Computers in Human Behavior, 26(3), 302-309. doi:10.1016/j. chb.2009.10.012.

O’Bannon, B. W., Lubke, J. K., Beard, J. L., \& Britt, V. G. (2011). Using podcasts to replace lecture: Effects on student achievement. Computers \& Education, 57(3), 1885-1892. doi:10.1016/j. compedu.2011.04.001.

O'Callaghan, F. V., Neumann, D. L., Jones, L., \& Creed, P. A. (2015). The use of lecture recordings in higher education: A review of institutional, student, and lecturer issues. Education and Information Technologies, 10, 1-17. doi:10.1007/s10639-015-9451-z.

Owston, R., Lupshenyuk, D., \& Wideman, H. (2011). Lecture capture in large undergraduate classes: Student perceptions and academic performance. The Internet and Higher Education, 14(4), 262-268. doi:10.1016 j.iheduc.2011.05.006.

Paechter, M., \& Maier, B. (2010). Online or face-to-face? Students' experiences and preferences in e-learning. The Internet and Higher Education, 13, 292-297. doi:10.1016/j.iheduc.2010.09.004.

Paechter, M., Maier, B., \& Macher, D. (2010). Students' expectations of, and experiences in e-learning: Their relation to learning achievements and course satisfaction. Computers and Education, 54(1), 222-229. doi:10.1016/j.compedu.2009.08.005.

Paechter, M., Kreisler, M., Luttenberger, S., Macher, D., \& Wimmer, S. (2013). Kommunikation in ELearning-Veranstaltungen. Erfahrungen der Studierenden und ihre Präferenzen für Online- oder Faceto-Face-Kommunikation. [Communication in e-learning courses. Students' experiences and their preferences for online or face-to-face communication.] Gruppendynamik und Organisationsberatung, 44(4), 429-442. doi:10.1007/s11612-013-0223-1.

Pekrun, R. (2006). The control-value theory of achievement emotions: Assumptions, corollaries, and implications for educational research and practice. Educational Psychology Review, 18, 315-341. doi:10.1007 /s10648-006-9029-9.

Pilarski, P. P., Alan Johnstone, D., Pettepher, C. C., \& Osheroff, N. (2008). From music to macromolecules: Using rich media/podcast lecture recordings to enhance the preclinical educational experience. Medical Teacher, 30(6), 630-632. doi:10.1080/01421590802144302.

Pintrich, P. R., \& de Groot, E. V. (1990). Motivational and self-regulated learning components of classroom academic performance. Journal of Educational Psychology, 82(1), 33-40. doi:10.1037/00220663.82.1.33. 
Pintrich, P. R., Smith, D., Garcia, T., \& McKeachie, W. J. (1991). The motivated strategies for learning questionnaire (MSLQ). Ann Arbor, MI: The University of Michigan.

Salomon, G. (1983). The differential investment of mental effort in learning from different sources. Educational Psychologist, 18(1), 42-50. doi:10.1080/00461528309529260.

Schulmeister, R. (2015). Abwesenheit von Lehrveranstaltungen. Ein nur scheinbar triviales Problem. Eine Meta-Studie von 300 empirischen Arbeiten. [Absenteism in university courses. Only at first sight a trivial problem. A meta-study of 300 empirical surveys.] University of Hamburg: Hamburg 2015. http://rolf. schulmeister.com/pdfs/Abwesenheit.pdf.

Schweizer, K., Paechter, M., \& Weidenmann, B. (2001). A field study on distance education and communication: Experiences of a virtual tutor. Journal of Computer-Mediated Communication, 6(2). http:/onlinelibrary.wiley.com/doi/10.1111/j.1083-6101.2001.tb00116.x/full.

Scutter, S., Stupans, I., Sawyer, T., \& King, S. (2010). How do students use podcasts to support learning? Australasian Journal of Educational Technology, 26(2), 180-191. doi:10.14742/ajet.v26i2.1089.

Snow, R. (1989). Aptitude-treatment interaction as a framework for research on individual differences in learning. In P. Ackerman, R. Sternberg, \& R. Glaser (Eds.), Learning and individual differences (pp. 1360). New York, NY: Freeman.

Steinmayr, R., \& Spinath, B. (2009). The importance of motivation as a predictor of school achievement. Learning and Individual Differences, 19(1), 80-90. doi:10.1016/j.lindif.2008.05.004.

Titsworth, B. S., \& Kiewra, K. A. (2004). Spoken organizational lecture cues and student notetaking as facilitators of student learning. Contemporary Educational Psychology, 29(4), 447-461. doi:10.1016/j. cedpsych.2003.12.001.

Toppin, I. N. (2011). Video lecture capture (VLC) system: A comparison of student versus faculty perceptions. Education and Information Technologies, 16, 383-393. doi:10.1007/s10639-010-9140-x.

Traphagan, T., Kucsera, J. V., \& Kishi, K. (2010). Impact of class lecture webcasting on attendance and learning. Educational Technology Research and Development, 58(1), 19-37. doi:10.1007/s11423-009-9128-7.

Walls, S. M., Kucsera, J. V., Walker, J. D., Acee, T. W., McVaugh, N. K., \& Robinson, D. H. (2010). Podcasting in education: Are students as ready and eager as we think they are? Computers \& Education, 54(2), 371-378. doi:10.1016/j.compedu.2009.08.018.

Wild, K. P. (2000). Lernstrategien im Studium. Strukturen und Bedingungen. [Learning strategies in academic studies.] Münster: Waxmann.

Williams, A. E., Aguilar-Roca, N. M., \& O’Dowd, D. K. (2016). Lecture capture podcasts: Differential student use and performance in a large introductory course. Educational Technology Research and Development, 64(1), 1-12.

Zimmerman, B. J. (1990). Self-regulated learning and academic achievement: An overview. Educational Psychologist, 25(1), 3-17. doi:10.1207/s15326985ep2501_2. 